\title{
Interconnections of urban systems: infrastructure, design and planning in relation to the presence of resilience - a case study in the city of Blumenau, Santa Catarina State, Southern Brazil
}

\author{
A. P. G. M. Pinto ${ }^{1} \&$ V. F. Fraga ${ }^{2}$ \\ ${ }^{1}$ Department of Architecture and Urbanism, \\ Fluminense Federal University, Brazil \\ ${ }^{2}$ Institute of Economics, Federal University of Rio de Janeiro, Brazil
}

\begin{abstract}
Natural catastrophes caused by torrential rain, for example, are of major concern nowadays since they can disrupt the functioning of a city's vital network, causing even irreversible damage to the socio-urban structure. It may be something dynamic, counterposed to the circumstantiality of the externalities to be realised in the concreteness of the local existence. Thus, fragile, inadequate or deteriorated infrastructure potentialises risks of natural catastrophes. On the other hand, the possible interconnections of the urban systems: infrastructure, design and planning, may present significant potential, from the perspective of resilience, to sustain the quality of life, and, above all, to ensure the survival of the city and its inhabitants. The central point of this study is to rethink such urban vulnerabilities in order to better explain the implications of the presence of resilience in the city. This reflection is based on Projeto Blumenau 2050, which has presented a plan with guidelines and projects for this city in Santa Catarina State, Southern Brazil, with respect to the territorial planning, devised after identification of its susceptibility to flooding, caused by torrential rainfall, mainly due to the El Niño phenomenon, which has hit this city over the last five years. Although adequate infrastructure is essential to urban design, according to the Brazilian Chamber of Commerce in 2013, the percentage of such investment in the country is much less than the average in cities in other emerging countries.
\end{abstract}


Therefore, Projeto Blumenau 2050 has stimulated permanent efforts to avoid disruption of such plans aimed at coping with these critical issues. Keywords: public policies, urban planning, urban systems, resilience.

\section{Introduction}

The central concern of this study refers to the warning, issued by humanitarian organisations in 2016, regarding the El Niño climatic phenomenon, which should raise the risks of hunger and disease for millions of people. According to William Patzert, a climate specialist at the NASA Jet Propulsion Laboratory, the El Niño should exacerbate droughts in some areas and accentuate floods in others. Besides this, he warns that its impact in 2015-2016 may be comparable to those in 1982-1983 and 1997-1998, which were the most damaging in the last century [1]. However, it is necessary to clarify that El Niño is not a phenomenon caused by global warming, due to the so-called greenhouse effect or any other thermal anomaly caused by man, such as deforestation, over the last few years [2]. Nevertheless, when these other phenomena coincide with El Niño, extraordinarily intense typhoons/cyclones can lead to effects of far greater proportions.

The referred phenomenon occurs between the west coast of Latin America and Southeast Asia, although its consequences may be felt throughout the world. In Brazil it has produced severe drought in the Northeast, while in the South and northern Argentina it has been responsible for flooding [1].

In the current conjuncture, the warming and other climatic alterations are aggravating occurrences, such as hurricanes, storms and even earthquakes; or the melting of the polar ice, increasing the sea level, inundating coastal regions and upsetting the environmental equilibrium.

In the United Nations Conference on the Environment and Sustainable Development, known as Rio-92, Eco-92 or the Earth Summit, held in June 1992, in Rio de Janeiro, the United Nations member countries signed the General Convention on Climate Change. After this event, they were expected to implement the appropriate international, national and regional strategies, aimed at achieving a global vision of the problem [3].

From the perspective of reducing the socio-environmental inequalities, in ECO-92, an accord was reached in which the developing countries would receive financial and technological support, the objective being to promote sustainable development, and the public authorities would adopt adequate measures to limit the harmful effects of vehicles and sanitation risks, to improve the management of natural resources, as well as to combat social exclusion and poverty. Equally, they should administrate the effects or consequences of climate change [4].

This study recognise the concentration of the benefits of development in the hands of the few, as well as the disproportionate levels of environmental risk faced by the poorest and most deprived ethnic groups, who remain vulnerable, off the agendas of governments and corporations [5, p. 15). Besides this, it considers climate change in Brazil, just as in the international scenario, as an issue of the environmentalists against the economic sectors that wish to expand, 
or against the traditional emitters of greenhouse gases, such as oil companies, automotive firms and iron/steel producers [6].

This statement gains greater weight when the impacts of exceptional episodes, especially those of an atmospheric nature, have particularly devastating results in the urban environment, potentially exceeding the absorptive capacity of the consequences by the society. The risks of being a disaster victim are distinct, the social strata bearing a direct relation to the type and magnitude of the impact, given that the degree of risk and the type of peril to which a person is subjected are closely linked to the standard of living [7].

Thus, in countries with a marked concentration of wealth, such as Brazil, it is possible to observe that the areas most lacking in infrastructure and basic services are most exposed to environmental risks and vulnerabilities, occupied by the population segment with the least power of mobility and accessibility to the cities, thus revealing the cumulative effects of socio-spatial segregation, or socio-territorial exclusion.

Herein lies this study's motivation, embodied in the project, Projeto Blumenau 2050, which is pioneering in its proposal for long-term strategic planning, dedicated to avoiding, reducing and recovering from damage arising from natural disasters, more specifically, heavy rain causing floods and landslides. Records of these phenomena date back to 1955, and they indicate that they have become progressively more frequent due to El Niño, compounded by disorderly urban sprawl, among other factors. It is noteworthy, therefore, that there is a possibility of interconnection among urban systems, emphasizing the presence of resilience in relation to the urban socio-spatial inequalities [8].

In these terms, this study: a) contextualises the socio-climatic challenges under focus; b) discusses public policies and their urban implications for this focus; c) presents a summary of Projeto Blumenau 2050; d) is oriented by a qualitative methodology; and e) sets out final considerations.

\section{Methodology}

This research seeks to understand the dynamic relation between a contextualised urban socio-environmental phenomenon and its management, from the perspective of the new public governance, that is, between the public documents put into practice and the ramifications of the problems associated to the occurrence of extreme events in the city. The interpretation of the phenomena, the attribution of meanings, and the basic steps in the investigation, required bibliographic and documental research, as well as a case study approach. It is recognised, however, that the study modality followed in this research is distant from Yin's [9] classification, a study of inestimable value with its deep reflections, demanding specificities of the highest calibre. However, the present study is not absolutely set apart from a case study, in view of the fact that it is limited to the South region of Brazil, more specifically Santa Catarina State, focusing on it as the victim of frequent, extraordinarily calamitous climatic events, incurring considerable socio-economic sequels, making Projeto Blumenau 2050 the significant focus of this study. 
The bibliographic groundwork included authors in the field of public policy, such as Wilheim, Monte-Mór, Moreira, Gomes and Santos, in order to investigate issues of socio-spatial inequality in the ordination of territory, as well as the history of the absence of investment in basic infrastructure emphasised by Harvey. Authors like Fraga, Nonni and Lefebvre contributed to a better perception of management, beginning with the planning and actions based on what has been experienced, considering the present time simultaneously with the need to be open to adjustments and advances observed in the scheduling of activities, determination of priorities, the needs of others, and periods for investments in Projeto Blumenau 2050.

On the other hand, the documental search of the IPEA, BNDES and IPEA reports favoured the definition and applicability of the concepts of social determinants, promotion of health, environmental conflict, as well as the definition and legal bases of the Plano Diretor [Master Plan]; besides surveys of secondary data, both numerical and qualitative, held by public and private institutions. The referred reports were also fundamental in finding infrastructural vulnerabilities and socio-spatial inequalities, and these aided analysis of Projeto Blumenau 2050, seeking to verify if this complied with the guidelines set forth in the regulation document - the master plan - as being fundamental to the plenitude of its social function.

Fundamentally, the methodological orientation in this research followed M. Q. Patton [10], due to the broad scope of his position - scientific rigor regarding the phenomenological philosophy - besides broadening the scientific conceptual complexity, enabling innovation, according to appreciation of his productions published by Sage and prizes awarded. Yin, considers qualitative research as being persons and implying the quality of the research whose choice in seeing is what really interests the researcher, the manner in which he himself sees the world, considering the context, including how things work [10, parts 1-13]. With reference to the work by Robert Kegan [11, p. 11], he reaffirms: "Being persons is the activity of giving meaning".

Following up Patton's review [10, module 4] about interpersonal interviews, there was a conversation with Rafael Mônaco, who had had a dual role as a regional citizen and a media professional, in fact a TV journalist at the time. He had accompanied the dramatic socio-ecological events under focus, listening to the problems of the populations affected, their worries, initiatives of solidarity and politico-administrative expectations. His intimate contact provided a more concrete perception of the situations experienced and a better understanding of the orientation for the future, manifested in Projeto Blumenau 2050.

\section{Public policies and urban planning}

In order to understand the remaining challenges in the urban planning, the probable factors that contributed to divergence between urban and non-urban public sector policies were extracted from the report, Desenvolvimento em Debate - Desenvolvimento Urbano: cidades sustentáveis e qualidade de vida [Development under Debate: sustainable cities and quality of life], issued by 
Banco Nacional de Desenvolvimento - BNDES [Brazilian Development Bank] [12]: I) the absence of a national policy in the urban development area, as well as a lack of implementation of efficient induction mechanisms that would guarantee adhesion of subnational entities to the programmes, as in the case of the cited sectorial policies; II) the urban programmes, such as for credit and investment, became particularly vulnerable to the Federal Government's fiscal situation, mainly because of the absence of constitutional or institutional protection.

3.1 As possible alternatives to the above, one may mention the need to formulate new policies to face the urban challenge, to strengthen the territory, even if the action remained sectorial, and to design new institutional arrangements for urban management, taking into consideration the political dimension and the promotion of partnerships. Above all, one must stress the importance of formulation of a national urban policy at federal level, essential to confront the Brazilian urban problems, taking into consideration the duality between the formal city and also the informal.

3.2 According to Wilheim [13], a collaborator in the referred report, inequality in cities must be faced on every level (intra and interurban, regional and national). The Brazilian cities, therefore, demand management strategies and urban planning tailored to their specificities. A significant increase in the institutional capacity of the municipalities is also indispensable for the referred local level report initiatives to be effective. In this context, policy change comes from changes in thinking and action on various levels. Harvey [14] emphasised the need to consider the political relations on multiple levels and to be attentive to the fact that, in the local ambit, these make contributions to change or reinforce the unequal geographical development. For the referred author, the accumulation of capital is indeed a geographical matter.

In the same manner, the urban network that articulates the economy, the society and globalised time-space, also organises territories of various amplitudes, ranging from micro-regional to continental. One may conclude that the metropolis-satellite relations, which have inspired interpretations about underdevelopment and international relations, have today gained an immense complexity in the face of the multi-level, fragmented, mutable dimension under the command of financial capital, more specifically the periphery of capitalism in the underdeveloped world [15, p. 61].

Such reflections illustrate that the dual questions of political action, as well as their possible negative and positive consequences, exert a direct influence on the city's urban planning. Fraga [16, p. 24], aligned with the thinking of Heller and Fehér [17], emphasised the need to clarify good and bad political consequences, something that has become extremely complex in today's globalised world, in which, for a long time, responsibilities have exceeded national boundaries.

It is worth stressing that, in the action plan, the confusion and inadequacies, to which the agent is subjected, do not prevent him/her from recognising these and 
their deficiencies, by means of his/her constant reflexive activity [18]. As an agent of knowledge, for Taylor [19], the individual tends to assess the qualities of his actions in the public space. Furthermore, returning to Fraga [16, p. 119], when the agent proposes to anticipate the consequence, he/she is referring to the sense, that is, to the possibility of its anticipation which will be related to the apprehension of the direction toward the need for action or to mere omission.

Based on the above, after the expiry of a short-term plan, this is not followed by an assessment, but rather by a new plan, devised by other technicians at the service of a successor political group. Even so, in successive attempts, it is possible to reach concrete conclusions. With regard to long-term urban planning, if it is followed without alterations by successive government leaders, it may even inhibit the moments of policy revision that may become necessary [20, p. 193], but, if associated to tactical planning, it is possible to formulate or reformulate the action plan, that is, favour a real planning process and change, as this determines in advance what must be done and which aims must be achieved, such as, alternatives envisaged to prevent or minimize the impact of natural catastrophes.

Finally, as the future is not a finished product, and even less can planning determine which decisions should be taken by men in the future, in vain, tactics are established for those who are not in power today [20, p. 65]. It is necessary, therefore, to observe the phenomenological time, according to which the present is not closed unto itself. Indeed, it reinforces the presence of the whole, it remains with the past and with the possibilities of what is to come [16, p. 19]. For Lefebvre [21], in other words, space holds within itself the seeds of a new type of space.

\section{Interconnections of the urban systems}

In Brazil, from the colonial towns to today's metropolises, the theoretical referentials have been redefined, adapted and recreated to explain the sociospatial processes and inform about the political projects of classes and interest groups, within and outside the State. On the one hand, there are the influences of the traditional North American urban sociology of the Chicago School with variations between the cultural approach and the so-called 'ecological'; on the other, the influences of the regional and urban economy, consolidated around regional science as of the decisive contribution by Walter Isard [15, pp. 61-65].

However, the progressive presuppositions have prevailed in the organisation of the Brazilian cities, materialised in the zoning and land use control. The zoning and the regulation of urban land use was aimed at solving a central contradiction of the capitalist city: the conflict between private ownership of land and the collective demands for integration and response to the co-operation implicit in urban space. Besides this, the commissions and/or technical organs of local planning have supposedly responded to the specific interests with impartiality, tending to mask the process of depoliticisation imposed on the city, subordinating it ever more to the needs for expansion and accumulation of capital, and, therefore, to the dominant classes $[15$, p. 70$]$. These relations are 
complex and very close when the space is hierarchised, as well as the powers exercised on it. Therefore, the formal dispositions (of law) that govern space and control its dynamics are also complex [22, p. 57]. In practice, as Monte-Mór [15] noted so well, the adhesion takes place in accordance with the interests of those who control the association and it can vary due to the different contexts of the moments.

In order to clarify the above, the legal instruments, like other complementary normative instruments, are mutable and tend to be reviewed according to the logic of perfection and progressivity, but are always related to formal territorial units that are also more or less stable [22, p. 39]. It constitutes, above all, a normative space where the different competencies and behaviour are classified according to a rigid division of the space. On the other hand, it is perceived that the division of the space loses the principal role of classifying the actions, these having previously referenced a group, a social identity.

The genesis of the space is the infrastructure relations, but the genealogy is due to the superstructure, even when it reflects capital interests. Therefore, the source of definition of the laws and norms that regulate the space is not the power of the State, but rather the terms of the modus operandi of the spatial regulation of the society [23]. Along general lines, the public and private agents behind these strategies, with greater power and political capacity, ignore or circumvent the law due to social disputes over power and control, marginalising actors confined to a particular level of action [24, 25].

Within the Brazilian urban reality, in an elevated local social context, the urban legislation may be conceived as a means of inducing alterations that go beyond their normative effect. In order to better illustrate this, Wilheim [20, p. 197] cites the example of the city of Joinville, located in southern Brazil, where diversification of land use and the application of different quotas for territorial and building taxes have resulted in densification in previously established areas.

Returning to the point regarding infrastructure, in 2006, in Marketing de Lugares: como conquistar o crescimento de longo prazo na América Latina e no Caribe (ALC) [Marketing of Places: how to conquer long-term growth in Latin America and the Caribbean (LAC)], Kotler et al. [26, p. 155], in relation to infrastructure as a consummate fact, he warned: "what was constructed with much effort by one generation may be lost in the next, if it is presupposed that water and sewage systems, bridges and tunnels will never need to be substituted."

Another important aspect is the verification that the majority of the LAC cities constructed expensive infrastructure on the expanding urban periphery and abandoned the urban environment already constructed in central regions, where governments are incapable of accomplishing the infrastructure demand and its maintenance [26, p. 161].

It must be said, therefore, that this territorial ordination is marked by the transformations in the technical composition, such as in relation to infrastructure investments, where it is verified that the norms of a technical order are also political [27]. According to Bernardes [28], the construction of the territory is a 
technical fact. Nevertheless, in essence, it is a social fact linked to the political ideological system.

Faced with these challenges, a vision opens up to a proposal for integrated strategic planning, and, beyond this, possibilities of interconnected urban systems may be foreseen, broadening into programmes for the environment, transport and energy conservation, which, according to Kotler et al [26], are usually conducted by separate public policies. Gradually, these will be linked in such a way that they will become progressively interdependent, including housing, zoning, public health and education.

\section{The Blumenau Project 2050}

The city of Blumenau has had a history of floods since the end of the 19th century, and, in the last two years, they have become recurrent, causing much damage and loss. It is worth mentioning that one of the significant tourist attractions, the Oktoberfest, began in 1984 precisely to collaborate with the recovery of the city and the self-esteem of the population after yet one more natural catastrophe due to heavy rain. According to Estudo Desastres Naturais: conhecer para prevenir [Study of Natural Disasters: knowing to prevent], the Instituto Geológico da Secretaria de Meio Ambiente do Governo do Estado de São Paulo [Geological Institute of the Environmental Secretariat, São Paulo State Government], the most frequent natural disasters in the south of Brazil are: floods, gale force winds and hail [29] (Fig. 1).

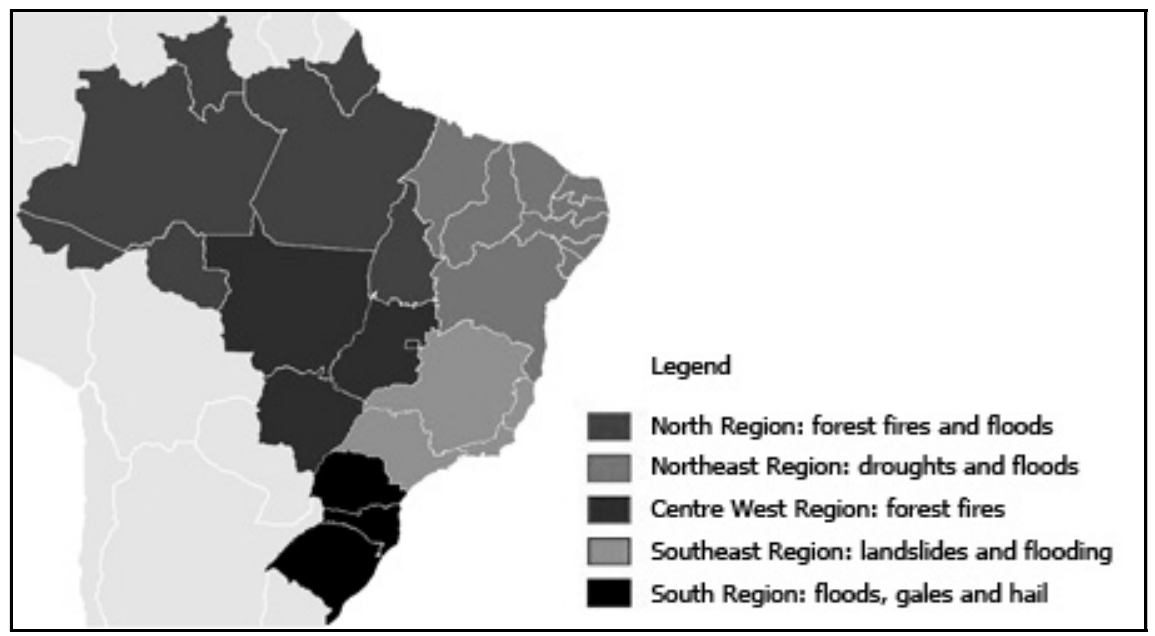

Figure 1: Map of Brazil's regions - natural disasters recorded by the Civil Defence.

In 2008, with the objective of reversing this process by making this city prepared in advance for the coming decades, the Programa de Desenvolvimento Urbano de Blumenau [Blumenau Urban Development Programme], devised by 
the municipal government, launched Projeto Blumenau 2050. This mentions the fact that "few are the Brazilian cities that were born from orderly planning, and Blumenau is no exception", observing that "from 1850, the year German settlement began, until the 1970s, the city's infrastructure was developed basically at moments of need, but have not always proven to be adequate in the long term [30, p. 3]. These reflections are in line with the previous points about the peculiarities and particularities of the urban policies, as well as the perceptions of Kotler et al. [26] after diagnosing the infrastructure fragility in Latin American and Caribbean (LAC) cities.

After the major floods of 1983 and 1984, which severely hit the urban area, the way occupation was practiced in Blumenau began to change. The Project stated that a new urban occupation had begun. In order to flee from the risk of floods, inhabitants had begun to move to the new areas and to demand infrastructure, which was not being built at the same rate. As a consequence, problems were generated in the municipal roadway system, as people constantly needed to journey to the city centre to work, go shopping and use services [30, p. 12].

Such implications provided the guidelines for Axis 1 - Land Use and Occupation, and Axis 2 - Transport Circulation System. Besides these, it was verified that there was some concern regarding simplification of the concept of use, defining parameters to evaluate impact, and also simplification of the zoning stratification. Besides the application of the legal and urban instruments, provided in the Estatuto da Cidade e Plano Diretor [City Statute and Master Plan], both were aimed, a priori, at collective welfare and social justice [30 p. 14].

The present Master Plan (3rd revision), issued in 2006, seeks to remedy this deficiency by providing integration among public investments and services and land occupation. Thus, Projeto Blumenau 2050 was designed to put this development aim into practice.

Awareness of the problem of the housing deficit, more specifically the question of social and territorial exclusion, provided the guidelines for Axis 4 Housing and Land Regularisation. For residents who, today, occupy risk or environmental preservation areas, an alternative to facilitate the acquisition of homes by low-income families has been presented in partnership with the Caixa Econômica Federal (government bank providing housing finance) [30, p. 33]. Besides developing parallel projects for environmental recovery, in the short term, it is planned to have preventive and participative inspection, educational programmes about urban land use and occupation, among others.

Regarding the matter of basic infrastructure, according to the Project's data survey, during the city's first 154 years of history, the residential sanitation coverage was only $2.12 \%$, considered a very low index, which had negative reflections as much on health as on the general quality of life, and on the environment as well. Therefore, Axis 5 - Sanitation and the Environment placed emphasis on devising and implementing the Código e Plano Municipal de Saneamento [Municipal Sanitation Code and Plan], the Plano Municipal de Recursos Hidricos [Municipal Water Resources Plan] in conjunction with the 
Comitê de Bacias do Itajai [Itajaí Basins Committee], among other measures [30, p. 36].

Besides this, it was intended to review and assess Agenda 21 de Blumenau. For a better appreciation of the 5 Axes and their guidelines, which structure the Projeto Blumenau 2050 [30, pp. 12-38], the following have been created, as shown in Table 1.

Table 1: Axes of action and their guidelines.

\begin{tabular}{|c|l|}
\hline Axes of action & Guidelines \\
\hline $\begin{array}{c}\text { 1 Land use and } \\
\text { occupation }\end{array}$ & $\begin{array}{l}\text { Maintain the large establishments involving commerce, } \\
\text { industry, health, education, leisure, culture and sport; } \\
\text { incentives for housing expansion is decentralisation of } \\
\text { new economic activities, equipment for health services, } \\
\text { leisure, culture and sport, taking maximum advantage of } \\
\text { the existing urban structure; encouragement of } \\
\text { reurbanisation and revitalisation of degraded urban areas; } \\
\text { control land use and occupation in areas prone to } \\
\text { flooding of up to 12 meters and in areas with risks of } \\
\text { landslides; review the configuration of buildings } \\
\text { currently permitted by law, propitiating better quality of } \\
\text { life, broadening the aeration and permeability of the soil. }\end{array}$ \\
\hline $\begin{array}{c}2-\text { Transport } \\
\text { circulation } \\
\text { system }\end{array}$ & $\begin{array}{l}\text { Adapt and structure the basic roadway system - urban } \\
\text { and regional; improve traffic flow - eliminate } \\
\text { bottlenecks; broaden the integrated public transport } \\
\text { system; implement alternative transport; reactivate } \\
\text { Quero-Quero airport. }\end{array}$ \\
\hline $\begin{array}{c}\text { 3- Interventions for } \\
\text { economic } \\
\text { development, } \\
\text { tourism and } \\
\text { leisure }\end{array}$ & $\begin{array}{l}\text { Structure and develop areas with potential for tourism, } \\
\text { sport and leisure; stimulate the economic development of } \\
\text { the municipality (construction of Porto Seco and } \\
\text { industrial districts for diverse activities). }\end{array}$ \\
\hline $\begin{array}{c}\text { 4- Housing } \\
\text { and land } \\
\text { regularisation }\end{array}$ & $\begin{array}{l}\text { Regularise and re-urbanise areas of irregular occupation; } \\
\text { relocate families occupying areas with landslide risks, } \\
\text { creating housing estates; avoid new irregular occupation; } \\
\text { treat housing as priority in public policy. }\end{array}$ \\
\hline $5-$ Sanitation and \\
the environment & $\begin{array}{l}\text { Create new water reservoirs, pumping systems, } \\
\text { distribution networks and long-distance pipelines; recycle } \\
\text { 100\% of the non-organic waste, the idea being to set up } \\
\text { sorting plants and electric power generators. }\end{array}$ \\
\hline
\end{tabular}

Besides these axes, different deadlines have been set to achieve the related goals: in the short term, until 2015; the medium, 2030; the long, 2050. By 
sharing Drucker's [31] vision, there will be periodic assessment of the planning project, viewing the results against the decisions taken, in relation to the expectations, through an equally organised systemic feedback.

At this point, it is possible to perceive that resilience showed itself more clearly among residents through the planned actions discussed above. Indeed, a manifestation of an inspired human strength which deserves the phenomenological qualification of "in common".

Thus, according to Nonni [32], as objectives of a well-directed policy in the urban planning of a city, one cannot ignore the singularity and the convergence of the following: the past - to be studied to confirm and integrate the history of the city in the options to be taken; the present - to administrate, with simple actions, limited validity periods, to be taken with care so as not to harm future strategies; the future - to govern by means of a long-range plan that will not be conditional upon contingencies.

Based on this presupposition, what is the probability of no occurrence of a new significant event during this period? In other words, according to the phenomenological understanding of time perception, the elimination of new facts will make each projection of the respective Axes not representative of the future. Thus, it is important to underline that the planning also requires reversibility and feedback from the decision-making process itself.

\section{Conclusions}

It is observed, therefore, that the differential lies in the detailing of the projects, actions and schedules arising from the guidelines defined by diagnosis, in which it is possible to become aware of the conditioning factors, deficiencies and potentialities of the Blumenau municipal territory. Noteworthy above all are the interconnections of the urban systems and the drafting of new normative documents, such as the aforementioned municipal plans, to meet the identified needs.

In conclusion, the five Axes of the Projeto Blumenau 2050 are not only forces of adaptation, but equally sources of change [...] always in a collective elaboration of the representations of the world in which mankind will find the strength for living together, to survive and to develop [33], thus stressing the presence of resilience in the planning, in the plan and in the city project as well.

\section{References}

[1] BBC BRASIL, www.bbc.com/portuguese/noticias/2016/01/160102_el nino_alerta_mv

[2] El Niño e La Niña - CPTE/INPE, http://enos.cptec.inpe.br/

[3] Lombardo, M. A., Mudanças climáticas recentes e ação antrópica. Revista do Departamento de Geografia da Universidade de São Paulo, 8, pp. 2934, 1994.

[4] IPEA, Sustentabilidade ambiental no Brasil: biodiversidade, economia e bem-estar humano, http://repositorio.ipea.gov.br/handle/11058/3220 
[5] Acselrad, H., Mello, C. C. do A. \& Bezerra, G. das N., O que é Justiça Ambiental? Garamond: Rio de Janeiro, pp. 15, 2009.

[6] Carta Maior, Meio Ambiente. Mudança Climática: o futuro é agora. http:/cartamaior.com.br/?/Editoria/Meio-Ambiente/Mudanca-climatica-ofuturo-e-agora/3/18162

[7] INPE, Vulnerabilidade das megacidades brasileiras às mudanças climáticas, http://megacidades.ccst.inpe.br/sao_paulo/VRMSP/ capitulo3. php

[8] O'Brien, K., Hayward, B. \& Berkes, F., Rethinking social contracts: building resilience in a changing climate. Ecology and Society 14(2): 12, 2009. http://www.ecologyandsociety.org/vol14/iss2/art12/

[9] Yin, R. K., Case Study Research: Design and Methods (Applied Social Research Methods). Thousand Oaks, CA.: Sage Publications Inc., 5th Edition, 2014.

[10] Patton, M. Q., Qualitative research \& evaluation methods: integrating theory and practice. Thousand Oaks, CA.: Sage Publications Inc., 2015.

[11] Kegan, R., The evolving self: problem and process in human development. Cambridge, MA: Harvard University Press, 1982.

[12] BNDES, Desenvolvimento em Debate - Desenvolvimento Urbano: cidades sustentáveis e qualidade de vida, http://www.bndes.gov.br/ SiteBNDES/bndes/bndes_pt/Institucional/Publicacoes/Consulta_Expressa/ Tipo/Livro/200212_50.html

[13] Wilheim, J., Cidades Sustentáveis no Período de transição da história. Desenvolvimento em Debate - Desenvolvimento Urbano: cidades sustentáveis e qualidade de vida. ed. E. Neves, J. Wilheim \& M. A. Melo, BNDES: Rio de Janeiro, pp. 329-336, 2002.

[14] Harvey, D., Espaços de esperança, Edições Loyola: São Paulo, pp. 81-94, 2004.

[15] Monte-Mór, R.L., As teorias urbanas e o planejamento urbano no Brasil, Economia regional e urbana: contribuições teóricas recentes, ed. C.C. Diniz \& M.A. Crocco, UFMG: Belo Horizonte, pp.61-85, 2006.

[16] Fraga, V.F., Gestão pela formação humana: uma abordagem fenomenológica, Manole: São Paulo, 2009.

[17] Heller, A. \& Fehér, F., A condição política e pós-modernidade, Civilização Brasileira: Rio de Janeiro, 2002.

[18] Araújo, P.R.M. de., Charles Taylor: por uma ética do reconhecimento, Loyola: São Paulo, pp. 68, 2004.

[19] Taylor, C., As fontes do Self: a construção da identidade moderna, Loyola: São Paulo, 1997.

[20] Wilheim, J., Cidades: o substantivo e o adjetivo, Debates 114, Perspectiva: São Paulo, 2008.

[21] Lefebvre, H., The production of space, Blackwell: Oxford, UK, 1994 (1972).

[22] Gomes, P.C. da C., A condição urbana: ensaios de geopolítica da cidade, Bertrand Brasil: Rio de Janeiro, 2012. 
[23] Moreira, R., O espaço e o contra espaço: as dimensões territoriais da sociedade civil e do Estado, do privado e do público na ordem espacial burguesa. Territórios, Territórios: ensaios sobre o ordenamento territorial, ed. M. Santos et al., Lamparina: Rio de Janeiro, pp. 95-97, 2007.

[24] Klink, J., Porque as regiões metropolitanas continuam tão ingovernáveis? Problematizando a reestruturação e o reescalonamento do estado (social) - desenvolvimentista em espaços metropolitanos. IPEA: Brasília, 2013.

[25] Swyngedouw, E., Neither global nor local: 'glocalization' and the politics of scale, Spaces of globalization, ed. K. Cox, Guilford Press: New York, pp. 137-166, 1997.

[26] Kotler, F., Gertner, D., Rein, I. \& Haider, D., Marketing de lugares: como conquistar crescimento de longo prazo na América Latina e no Caribe. Prentice Hall: São Paulo, 2006.

[27] Santos, M., A natureza do espaço: técnica e tempo, razão e emoção. HUCITEC: São Paulo, 1996.

[28] Bernardes, J.A., Mudança técnica e espaço: uma proposta de investigação. Geografia: conceitos e temas, ed. I.E. de Castro, P.C. da C. Gomes \& R.L. Corrêa, Bertrand Brasil: Rio de Janeiro, pp. 244, 1995, 2000.

[29] Instituto Geológico de São Paulo, Desastres Naturais: Conhecer para prevenir, Naturais.pdf

[30] Prefeitura de Blumenau, Revista Blumenau 2050, www.blumenau.sc. gov.br/downloads/seplan/revista_blumenau_2050.pdf

[31] Drucker. P., The age of discontinuity, Heinemann: London, 1969.

[32] Nonni, E., Una nuova urbanistica: è possibile. INU: Roma, pp. 45, 2013.

[33] Sainsaulieu, R. \& Kirschner, A. M., Sociologia da empresa: organização, poder, cultura e desenvolvimento no Brasil. DP\&A: Rio de Janeiro, pp. $171,2006$. 